\title{
BMJ Open Evaluating the effect of income support policies on social health inequalities (SHIs) at birth in Montreal and Brussels using a contextualised comparative approach and model family method: a study protocol
}

Mouctar Sow, ${ }^{1,2,3}$ Myriam De Spiegelaere ${ }^{2}$ Marie-France Raynault ${ }^{1,3}$

\section{To cite: Sow M, De}

Spiegelaere M, Raynault M-F. Evaluating the effect of income support policies on social health inequalities (SHIs) at birth in Montreal and Brussels using a contextualised comparative approach and model family method: a study protocol. BMJ Open 2018;8:e024015. doi:10.1136/ bmjopen-2018-024015

- Prepublication history for this paper is available online. To view these files, please visit the journal online (http://dx.doi org/10.1136/bmjopen-2018024015).

Received 8 May 2018 Revised 1 June 2018 Accepted 4 June 2018
D) Check for updates

(c) Author(s) (or their employer(s)) 2018. Re-use permitted under CC BY-NC. No commercial re-use. See rights and permissions. Published by BMJ.

For numbered affiliations see end of article.

Correspondence to Mouctar Sow; mamadoumouctar.sow@ umontreal.ca

\section{ABSTRACT}

Introduction Assessing the effects of social policies on social health inequalities (SHIs) is a complex issue. Variations in social policy between countries or regions provide natural experiments in policy implementation to perform comparative research. Comparisons are most enlightening when: the object of the evaluation is well defined (types of policies, population groups); the context of policy is analysed (history, implementation); the impact of policy on household poverty is outlined in detail; the influence of various factors (other than poverty) on $\mathrm{SHI}$ is taken into consideration.

Methods and analysis This study aims to understand how income support policies (ISPs) in Brussels and Montreal influence the poverty level of households receiving social assistance, and how they are associated with SHI at birth. Two cases studies will be carried out from a comparative perspective. The analysis includes four stages : (1) The model family method will be used to compare ISPs and their impact on disposable income and poverty of households receiving social assistance in both regions. (2) Statistical analysis of administrative databases will enable the description and comparison of SHI in adverse pregnancy outcomes across the two regions. (3) Analysis of databases and documents will allow for description of various factors which are likely to interact with poverty and influence SHI at birth. (4) Based on the Diderichsen model, results from the previous stages will be used to formulate hypotheses about the mechanisms by which ISPs contribute to increasing or reducing SHI at birth in both regions.

Ethics and dissemination This research was approved by the Human Research Ethics Committee for Health research of Université de Montréal. In Belgium, the access to linked databases was approved by the Commission for the Protection of Privacy. Databases de-identified according to Belgian and Canadian legislation will be used. Results will be disseminated in scientific publications and will be shared with policy makers and field actors through collaborations with local organisations in Brussels and Montreal.
Strengths and limitations of this study

- In-depth comparison of two contexts similar in many ways but with significant differences in social policy offers a valuable opportunity to evaluate the potential impact of these policies on social health inequalities (SHIs), based on natural experiments in policy implementation.

- The model family method allows for analysis of poverty at the household level, to compare the poverty gap of various types of households across both contexts and informs hypothesis formulation on SHI at birth.

- Nevertheless, this method is illustrative rather than representative, as it analyses the household poverty based on their theoretical rights (legislation on eligibility conditions and entitlement criteria), and not real access to the services to which they are eligible.

- Moreover, the difference in income data sources across both regions renders the comparison of income-related health inequalities less than ideal.

\section{BACKGROUND}

Social policy: a major lever to reduce social health inequalities at birth

Social health inequalities (SHIs) result from the unequal distribution of resources, which allows people to have more or less control over their living circumstances and their health. ${ }^{1-3}$ Economic resources are particularly important as they can be 'transformed' into other types of resources. They determine access to material goods and influence social participation. ${ }^{4-7}$ These kind of resources have a considerable impact on the population's health and on certain groups in particular, such as children. ${ }^{8-15}$ Through the redistribution of economic resources, social policies contribute to reduce the poverty of 
households and economic inequalities. They constitute a major lever to improve the population's health and diminish SHI. ${ }^{715-21}$

One of the major recommendations to reduce SHI consists of improving children's health as early as possible, especially through policies which increase families' income and contribute to reducing the intergenerational transmission of poverty. ${ }^{19} 2022$ It is indeed well established that poverty before and during pregnancy is associated with an increased risk of stress and poor health for the mother, which in turn affects the child's health at birth (preterm birth, low birth weight). The family's poverty and/or health problems at birth have a negative effect on all aspects of the child's development (cognitive, health and behavioural) as well as on health in adulthood. ${ }^{123-26}$ Between rich countries, poverty and economic inequalities are the main factors that explain the differences in health inequalities in terms of infant mortality and adverse pregnancy outcomes. ${ }^{27} 28$

Although there is a consensus on the importance of social policy as a means to reduce income inequalities, to improve health and to reduce SHI from birth, few studies examine the way in which many components of these policies interact to influence household poverty and to accentuate or mitigate SHI in different contexts. ${ }^{11} 2930$ The scarcity of such evaluative studies is due, in particular, to the complexity of the task: multicausality (inter-relation between many types of policies, influence of others contextual factors), impossibility to carry out experimental studies, long-term health effects, and so on. ${ }^{31}$ Comparing different contexts with significant social policy differences constitutes a relevant approach to analyse the effect of these policies on SHI. ${ }^{29} 3032$ Indeed, variations in social policy between countries or regions provide an opportunity, based on natural experiments, to investigate the mechanisms by which these policies influence SHI in each context. ${ }^{11} 2933$

\section{The targeting effect of income support policies}

The policies that contribute to improve the income of households present two features: (1) They are a conjunction of numerous measures from various social policies, pursuing a variety of goals. ${ }^{34-39}$ These measures can be grouped into two categories: those aimed at non-working households or low-income households (unemployment benefits, social assistance benefits, measures that facilitate access to services such as housing, transport or healthcare) and those aimed at helping families with children (mainly child benefits and childcare). These governmental aids are delivered in several forms, whose combination varies by the country: direct financial help, tax deductions, subsidies for services. (2) These measures are applied according to various selectivity and generosity criteria. ${ }^{39-43}$ The selection of the beneficiary households for each programme and the amount allocated depends on many criteria including most notably the following: income, employment status (full time or part time), household composition (single parents, number of children and their ages) and other specific criteria: disabilities, citizenship, residence status and so on. These targeting criteria vary according to the applicable measure and according to the country, which entails a differential impact of income support policies (ISPs) on the income of different types of families inside a country and across countries, which is called targeting effect. In other words, a single mother with two children, unemployed, could be entitled to more or less benefits depending on their country of residence. The same goes for other family configurations. The comparative evaluation of social policies should reveal this targeting effect and the differential impact on the poverty of households in different contexts.

\section{The limits of usual studies on the links between social policy and SHI}

This is a relatively recent research field. Most research consists of quantitative studies analysing the correlation between the characteristics of social protection systems and health indicators. They are for the most part based on welfare state typologies (categorising the social protection systems of industrialised countries) and analyse the correlation between these regimes, poverty rates and health indicators. ${ }^{30} 324$ The most influential classification, proposed by Esping-Andersen ${ }^{45}$ (later adapted by other authors ${ }^{3044}$ ), distinguishes three regime types: liberal, conservative and social democrat. The latter is said to have the most state intervention: relatively generous universal benefits, a significant redistribution and a strong commitment towards equality.

These typologies are an interesting starting point to analyse the relation between different social protection systems and the population's health. For example, several studies show that Scandinavian countries (social democrat systems) have better indicators in terms of infant mortality. ${ }^{30}$ Yet these typologies have some limitations. ${ }^{30244}$ First, some results of studies based on these typologies are inconsistent. They vary especially according to the health indicators considered, the period and gender. Second, and most importantly, they are global macrosocial analyses which do not allow to decompose the support granted by the state into its many components nor to understand how these components interact to influence the poverty of households and contribute to SHI in different contexts. The regimes that they describe constitute ideal types which fail to reflect the diversity of the real state action. Even when states have the same social policy regime, they diverge in several aspects, such as its components, the selection process and the generosity. ${ }^{43}$ Even within a state, there can be important regional differences in the conception of social policy. Studies based on welfare state types fail to reveal such differences between states or regions and the potential impact they might have on different population groups. Their contribution is somewhat limited when it comes to identifying concrete political measures to reduce SHI. Moreover, these studies often analyse the effect of the welfare state on population health rather than SHI. 
The need to study contexts in order to overcome these limitations

As some authors highlight, there is a need for studies which evaluate in detail specific policies in different contexts with different methods. In order to better analyse the influence of social policy on SHI, a comparative analysis must take into account the specificity of contexts. ${ }^{30} 33444647$ The comparison is more enlightening when it relates to specific policies instead of state policy as a whole and analyses its effect on specific sociodemographic groups. Such is the case with Burstrom et als study, ${ }^{33}$ which compares single mothers with mothers in a couple, living in three countries with different family policies regime, on several factors: sociodemographic characteristics, living conditions (poverty, unemployment), lifestyle (tobacco use) and self-reported health. This study is interesting for its explanatory perspective, showing single mothers as a particularly disadvantaged group in all countries. It also reveals important differences in the mother's situation between countries, which reflect differences in family policies. The authors do point out a limitation in their study. A subgroup analysis was not carried out to account for the heterogeneity of single-parent households. Indeed, these households differ in particular according to the number of children. An analysis of the poverty level of single-parent households according to the number of children could reveal subgroup differences across countries. Moreover, present day social policy is not neutral, as it is influenced by historical and sociopolitical factors, which need to be highlighted as well. ${ }^{48} 49$

Our review of the literature shows that to better understand the mechanisms by which social policy contributes to reduce or increase SHI in different contexts, it is important to: (1) Clearly specify the object of the evaluation (types of policies, population groups). (2) Analyse the context of policy (historical, implementation). (3) Analyse the impact of policy on the poverty of different subgroups in each context. (4) Take into account contextual factors, other than poverty, which may interact with poverty and influence SHI in each context.

\section{RESEARCH PROPOSAL}

\section{Research questions and hypotheses}

This research aims to explore the link between ISPs, the poverty level of households receiving social assistance and unfavourable pregnancy outcomes, through a Brussels-Montreal comparison, in order to formulate hypotheses on the mechanisms by which these policies contribute to increase or decrease health inequalities at birth in both regions.

\section{Research questions}

1. What similarities and differences can be observed in health inequalities at birth between both regions?

2. What are the similarities and differences in terms of ISP implementation in both regions?
3. What is the impact of ISP on the poverty of households receiving social assistance in both regions?

4. To what extent do differences in household poverty contribute to explain the health inequalities at birth observed in Brussels and Montreal?

\section{Hypotheses}

Differences in the conception of ISPs in both regions (composition, selection process and generosity) influence the available income and the poverty level of low-income households.

The poverty level of these households, which varies according to the type of household and from region to region, helps to explain the extent of unfavourable pregnancy outcomes and SHI at birth in both contexts.

\section{The choice of cases}

Brussels and Montreal are two regions that present numerous similarities. The poverty ${ }^{5051}$ and recent immigration rates are high in both cities, with approximately $50 \%$ of births being to immigrant families. ${ }^{52} 53$ The two regions are located in two industrialised countries with a comparable level of economic development and quality of healthcare. A public health insurance system guarantees access to healthcare, especially for the most precarious. Perinatal health indicators in the general population in Brussels and Montreal are also comparable. ${ }^{5253}$

These two regions also present notable differences in the conception of ISPs. A first glance reveals significant differences and similarities in terms of child benefits ${ }^{5455}$ and social assistance policy. ${ }^{56-58}$ In Quebec and in Brussels, child benefits are universal, with an extra supplement granted to some households according to various criteria. The amount is significantly greater in Quebec (where it is provided both by the province and the state), and it increases considerably for lower-income households. In Belgium, household income does not generally determine the amount of benefits. Supplements may be granted on the basis of income if the parent is receiving social assistance, is single, disabled or unemployed for at least 6 months. Child benefits increase with the child's age and especially with their rank (third and beyond $>$ second $>$ first), whereas in Quebec they decrease from the first to the second child. Social assistance is relatively much more substantial in Belgium than in Quebec. Single-parent families and those with children receiving social assistance are entitled to extra benefits. Social assistance recipients receive further help through services (non-monetary or subsidies) such as priority access to social housing, extra healthcare reimbursements and free transport passes.

These differences between the two regions prompt the following initial remarks: (1) Single parenthood and number of children are two important dimensions when it comes to analysing income inequalities between households in the two regions. (2) In Quebec, child benefits (generous and income based) greatly contribute to increase the income of households receiving social 
assistance. The situation of households with children should be relatively more advantageous than that of households without children. This is consistent with the high levels of poverty among households without children in Quebec. (3) In Brussels, social assistance and non-monetary services should constitute an important part of the income of social assistance recipients. The fact that the basic child benefits are less generous than in Quebec might entail a relative disadvantage for households with children with respect to those without children.

However, this preliminary analysis must be nuanced by taking into account the increased child benefits for households on social assistance in Belgium, supplements based on single parenthood and the number of children, and the differential impact of services, so that the situation of various subgroups in both regions can be compared in detail. For the analysis of perinatal health inequalities, the differences observed between households in the two regions, according to the presence or not of children, make it relevant to compare the perinatal health indicators of children from primiparous mothers (firstborn) to those of children of multiparous mothers.

\section{Methods and analysis}

Two case studies will be carried out from a comparative perspective. Data collection and the comparative analysis will be done in four phases that will overlap over time.

\section{Phase I: comparative analysis of ISPs: family type method}

The family type method is best suited to analyse the targeting effect of ISP. Unlike macrosocial analyses, the poverty level (poverty gap) estimation is carried out at a microsocial level, namely the household level. It consists of estimating and comparing the available income of various households, either within a country or between countries, taking into consideration the policies which contribute to the household's well-being. ${ }^{36}{ }^{39-415960}$ The method presents three main advantages: (1) It allows to quantify the income and poverty level of each type of household. For instance, we will estimate the income of a household with a single parent, two children, receiving social assistance, depending on the country of residence. (2) We can include all sources of government support (cash benefits, tax benefits and non-monetised services) in order to calculate all the available household income. (3) It is thus possible to analyse the specific impact of one or many policies on the available income of families and therefore identify the policy components in which each country performs better or worse. In sum, the family type method allows to quantify the available income and to compare the poverty level of different family types between countries, as well to understand how it is affected by different components of ISP. This type of analysis cannot be done using data on social benefit expenditure.

The analysis will focus on households receiving social assistance, which are particularly poor and vulnerable to poor health. ${ }^{6162}$ They are mainly households without working income and the financial aid they receive from government comes from two main sources: social assistance and child benefits. These are the two main measures we will analyse. Access to social assistance can give access to various subsidies for different services, which vary according to country and have an impact on household income. We will consider mainly social housing and childcare services.

The analysis will be carried out in four stages:

\section{Comparative analysis of income support measures}

The policy implementation process will be described in detail for both regions. The differences and similarities in ISP contents will be brought forward by comparing existing legislation (eligibility criteria, amount granted). The interpretation of the results will take into account the history of these policies, especially the factors that influenced certain political decisions in both contexts. The data will be collected based on the analysis of the literature (grey and scientific) and through meetings with experts. The analysis will be guided by a comparative grid of family policies, proposed by Dandurand and Kempeneers. ${ }^{38}$

\section{Defining household types}

Based on the previous stage, many family configurations will be considered, taking into account the two main criteria: single parenthood and number of children. Single-parent and two-parent households, with one, two and three children will be compared. Households without children will also be considered.

\section{Calculating household disposable income}

The disposable income of a family corresponds to the sum of market income (salaries, investments) minus taxes plus government transfers payment. In the case of households receiving social assistance (without employment income), only government transfers are relevant to consider. Data will pertain to the 2015 period.

\section{Estimating household poverty}

The poverty level, precisely poverty gap, of each household type will be calculated from the gap between the available income and the relative poverty threshold corresponding to each family configuration. We will consider the relative poverty thresholds (at $50 \%$ and $60 \%$ of the national median income) in both countries. The gap between the available income and the relative poverty threshold will be expressed as a percentage of the relative poverty threshold in order to highlight the income a household would need to reach the threshold in each context. Eventually, using the family type method will allow us to analyse poverty at a household level, to compare the situation of different subgroups in the two contexts, and thus contribute to formulate hypotheses on SHI at birth in both regions.

\section{Phase II: analysis of SHI at birth}

A statistical analysis of administrative databases will enable to describe and compare the inequalities in 
adverse pregnancy outcomes between the two regions. The analysis covers three pregnancy outcomes: low birth weight, preterm birth and small for gestational age; which are three factors likely to negatively influence the child's development and their future adult health. In each region, these outcomes will be analysed according to two socioeconomic factors: income and being a recipient of social assistance or not, using multivariate models. The household's annual income will be categorised in quintiles and deciles so as to approach the families' situation from a relative standpoint (relative measures, rather than absolute ones, are recommended for international comparisons). ${ }^{63}$ In Montreal, we will use an ecological income measure (at the dissemination area).$^{6465}$ Then we will compare those families which received social assistance the year before birth with those that didn't. We will also analyse health inequalities in relation to the parent's level of education and single parenthood.

The analysis will also considerate migration. Many studies show that the relation between adverse pregnancy outcomes and socioeconomic factors varies according to the parent's migration characteristics. ${ }^{66-71}$ In each country, the analysis will hence compare non-immigrant mothers and various groups of immigrant mothers (according to the birthplace). The comparison will concern three axes: the mother's socioeconomic profile, the prevalence of adverse pregnancy outcomes and the risk of adverse pregnancy outcomes according to socioeconomic indicators.

The data arise from administrative databases in both regions. In Brussels, the birth register has been linked to the socioeconomic data (social security files) and migration data (national register files) of both parents, for the 2004-2010 period. In Montréal, we will use the birth register from the Quebec province, 2003-2012 period. Ecological income will be integrated to the births file (based on the postcode).

\section{Phase III: analysis of other factors that can interact with poverty} and influence SHIsat birth

If poverty is an essential element influencing SHIs, it should be kept in mind that the effect of poverty on health may be mitigated or exacerbated by other factors, which should also be taken into account. We will examine, mainly, the profile of very low-income households, the economic inequalities and the lifestyles of mothers during pregnancy. The profile of social assistance recipients (household composition factors) will be described through variables contained in the databases (duration of social assistance, migration status, education, family composition, etc) and by using the available literature. Multivariate analysis will highlight the impact of these characteristics on perinatal health. Economic inequalities constitute a complementary dimension of poverty. They reinforce the effect of poverty on health. ${ }^{72-74}$ The extent of these inequalities in both regions will be compared using the Gini coefficient and IQR. The prevalence of tobacco uses during pregnancy (general population and various subgroups) will be analysed based on available literature.
Phase IV: link between ISPs and health inequalities at birth: Diderichsen model

The results from the previous phases will be used to elaborate hypotheses on the mechanisms by which policy contributes to explain the differences observed in terms of SHI at birth in both regions. The analysis will be based on the model developed by Diderichsen et al. ${ }^{75}$ This model assigns social positions a key role in the process driving SHI. It reveals four mechanisms producing and maintaining SHI : The economic context creates a social stratification and assigns each individual a social position (mechanism I). That position exposes each individual to factors (material, psychosocial and lifestyle) with positive or negative effects on their health (mechanism II). The further down an individual falls on the social ladder, the more disease risk factors increase and the protection factors decrease, which makes them more vulnerable to illness (mechanism III). The differential exposition and differential vulnerability explain the differential illness frequency according to social position (health gradient). Lastly, the social and economic consequences of illness are worse for individuals who are lower on the social ladder (mechanism IV). The explanatory analysis will focus primarily on the first three mechanisms. Household poverty (a major risk factor of adverse pregnancy outcomes) will be at the heart of the analysis. We will show how policy decisions expose different population subgroups to poverty in both contexts and how poverty interacts with other factors to make some groups more vulnerable in terms of perinatal health.

\section{Patient and public Involvement statement}

Patients were not involved in this study.

\section{RESEARCH RELEVANCE}

This research is at the intersection of many fields, especially political science, social epidemiology and health promotion. It is aimed to illustrate the potential contributions that can be made through the integration of methods from social sciences with the field of evaluation of social policy on health. The evaluation approach is consistent with the health impact assessment approach. ${ }^{76}$ The analysis is in line with authors who recommend a better appreciation of many dimensions of context and the use of a variety of methodologies in order to find the mechanisms driving SHI. ${ }^{77-79}$ Eventually, this research can enable the identification of policy measures which may reduce the poverty of households and SHI at birth.

\section{LIMITATIONS}

\section{Model family method limitations}

The analysis is illustrative rather than exhaustive, as it treats theoretical rights. It does not encompass all the situations that households encounter. Indeed, the rights are not always automatically activated, either because the eligible persons do not request it for various reasons (no take-up), or because the available resources do not 
make it possible to satisfy all the requests. The two main measures analysed, social assistance and family allowance, are less concerned by this remark since, generally, the rights become active if the eligibility conditions are met. It is especially in terms of access to services, such as social housing, that significant differences could be found between different types of households within a region, and between the two regions. Do not take into account the difficulties of access to social housing for some households would lead to underestimation of the poverty of these households. The analysis will consider possible differences between the two regions in this respect.

Moreover, other income sources are not addressed by the model family method (family and community support, undeclared work). Also, ISPs often undergo changes (often minor ones) with potential impact on the available household income. Attention will be given to such changes in the period covered by the study. Any comparative effort, based on the model family method, requires equal hypotheses for each country. It is advised to compare few countries with a small number of case types so as to look at the families' situations as exhaustively as possible.

\section{Income-related health inequalities cannot be completely comparable}

The Brussels income data are taken directly from the yearly household income whereas the Montreal data are ecological, in relation to the average income of the neighbourhood. This might entail some difficulties when attempting to compare very low-income groups and income-related health inequalities. Nevertheless, geographical data are allowed as proxies of the individual situation when the zones are defined in such a way as to have a high socioeconomic homogeneity. The more homogeneous a zone is in this respect, the more the data reflect the situation of a composite or average person. Using this kind of indicator is relevant in urban centres with high density populations and high homogeneity, ${ }^{6580}$ as is the case with Montreal.

\section{Other potential confounding factors not taken into account in the quantitative analysis of SHI}

There are multiple perinatal health determinants. ${ }^{27} 82$ Factors which are not included in the multivariate models might diverge between the countries and contribute to the observed health inequalities. However, the analysis will take migration into account, one of the main factors influencing the relation between poverty and SHI. Based on the available literature, others factors, such as smoking during the pregnancy, will be compared in both regions. Attention will also be given to the aspects of the healthcare system, especially access to perinatal healthcare, which may differ between the two regions. Moreover, the comparative design of the study should ensure a comparability of both regions on several dimensions.

\section{Author affiliations}

${ }^{1}$ Département de médecine sociale et préventive, Ecole de santé publique de I'Université de Montréal (ESPUM), Montreal, Quebec, Canada

${ }^{2}$ Ecole de santé publique, Université Libre de Bruxelles, Brussels, Belgium

${ }^{3}$ Centre de recherche Léa Roback sur les inégalités sociales de santé de Montréal, Université de Montréal, Montréal, Canada

Contributors MS conceptualised the study. MDS and M-FR contributed to the design of this study. MS prepared the initial manuscript and MS, MDS and M-FR significantly contributed to revising it. All authors read and approved the final manuscript.

Funding This research was supported by Fonds National de la Recherche Scientifique (FNRS-Belgium) grant number ( $n^{\circ}$ 22329302), Fonds de la Recherche du Québec-Société et Culture (FRQSC) grant number (197077), and Lea Roback research Centre on social inequalities in health of Montreal.

Competing interests None declared.

Patient consent Not required.

Ethics approval Approval was obtained from the Université de Montréal health research ethics board (\# 15-004-CERES-D) and the Belgian Commission for the Protection of Privacy (\# STAT 04-2014).

Provenance and peer review Not commissioned; peer reviewed for ethical and funding approval prior to submission.

Data sharing statement Belgian data are available from the authors upon reasonable request and with permission of the Commission for the Protection of Privacy (CPP). Canadian data are available at the Québec Inter-University Center for Social Statistics (QICSS).

Open access This is an open access article distributed in accordance with the Creative Commons Attribution Non Commercial (CC BY-NC 4.0) license, which permits others to distribute, remix, adapt, build upon this work non-commercially, and license their derivative works on different terms, provided the original work is properly cited, appropriate credit is given, any changes made indicated, and the use is non-commercial. See: http://creativecommons.org/licenses/by-nc/4.0/.

\section{REFERENCES}

1. Whitehead M. The concepts and principles of equity and health. Int $J$ Health Serv 1992;22:429-45.

2. Marmot M, Friel S, Bell R, et al. Closing the gap in a generation: health equity through action on the social determinants of health. Lancet 2008;372:1661-9.

3. Graham H. Social determinants and their unequal distribution: clarifying policy understandings. Milbank Q 2004;82:101-24.

4. Lundberg $\mathrm{O}$, Yngwe MA, Stjärne MK, et al. The role of welfare state principles and generosity in social policy programmes for public health: an international comparative study. Lancet 2008;372:1633-40.

5. Marmot M. The influence of income on health: views of an epidemiologist. Health Aff 2002;21:31-46.

6. Lynch J, Kaplan G, position S. In: Berkman LF, Kawachi I, eds. Social epidemiology. Oxford: Oxford University Press, 2000:13-35.

7. Lundberg O, Fritzell J, Åberg Yngwe M, et al. The potential power of social policy programmes: income redistribution, economic resources and health. Int J Soc Welf 2010;19:S2-13.

8. Nelson K, Fritzell J. Welfare states and population health: the role of minimum income benefits for mortality. Soc Sci Med 2014;112:63-71.

9. Spencer $\mathrm{N}$. The effect of income inequality and macro-level social policy on infant mortality and low birthweight in developed countries--a preliminary systematic review. Child Care Health Dev 2004;30:699-709.

10. Komro KA, Livingston MD, Markowitz S, et al. The Effect of an Increased Minimum Wage on Infant Mortality and Birth Weight. Am J Public Health 2016;106:1514-6.

11. Spencer RA, Komro KA. Family Economic Security Policies and Child and Family Health. Clin Child Fam Psychol Rev 2017;20:45-63.

12. O'Campo P, Urquia M. Aligning method with theory: a comparison of two approaches to modeling the social determinants of health. Matern Child Health J 2012;16:1870-8.

13. Forget EL. New questions, new data, old interventions: the health effects of a guaranteed annual income. Prev Med 2013;57:925-8. 
14. Rodgers GB. Income and inequality as determinants of mortality: an international cross-section analysis. 1979. Int J Epidemiol 2002;31:343-51.

15. Duncan GJ, Brooks-Gunn J. Family poverty, welfare reform, and child development. Child Dev 2000;71:188-96.

16. Scheil-Adlung X. Response to health inequity: the role of social protection in reducing poverty and achieving equity. Health Promot Int 2014;29(suppl 1):i59-67.

17. Ferrarini T, Nelson K, Sjöberg O. Decomposing the effect of social policies on population health and inequalities: an empirical example of unemployment benefits. Scand J Public Health 2014;42:635-42.

18. Engster D, Stensöta HO. Do Family Policy Regimes Matter for Children's Well-Being? Soc Polit Int Stud Gend State Soc 2011;18:82-124.

19. Saunders M, Barr B, McHale P, et al. Key policies for addressing the social determinants of health and health inequities. Copenhagen: WHO Regional Office for Europe, 2017.

20. Bell R, Donkin A, Marmot M. Tackling structural and social issues to reduce inequities in children's outcomes in low to middle-income countries. Florence: UNICEF Office of Research, 2013.

21. Bourque M, Quesnel-Vallée A. Politiques sociales : un enjeu de santé publique ? Lien social et Politiques 2006;55:45.

22. Marmot M, Bell R. Fair society, healthy lives. Public Health 2012;126(Suppl 1):S4-10.

23. Aizer A, Currie J. The intergenerational transmission of inequality: maternal disadvantage and health at birth. Science 2014;344:856-61.

24. Aber JL, Bennett NG, Conley DC, et al. The effects of poverty on child health and development. Annu Rev Public Health 1997;18:463-83.

25. Braveman $P$, Barclay C. Health disparities beginning in childhood: a life-course perspective. Pediatrics 2009;124 Suppl 3(Supplement):S163-75

26. Béatrice N, Lise $\mathrm{G}$, Victoria ZM, et al. Longitudinal patterns of poverty and health in early childhood: exploring the influence of concurrent, previous, and cumulative poverty on child health outcomes. BMC Pediatr 2012;12:141.

27. Kim D, Saada A. The social determinants of infant mortality and birth outcomes in Western developed nations: a cross-country systematic review. Int J Environ Res Public Health 2013;10:2296-335.

28. Sidebotham P, Fraser J, Covington T, et al. Understanding why children die in high-income countries. Lancet 2014;384:915-27.

29. Komro KA, Burris S, Wagenaar AC. Social Determinants of Child Health: Concepts and Measures for Future Research. Health Behav Policy Rev 2014;1:432-45.

30. Bergqvist $\mathrm{K}$, Yngwe MA, Lundberg $\mathrm{O}$. Understanding the role of welfare state characteristics for health and inequalities - an analytical review. BMC Public Health 2013;13:1234.

31. Braveman P, Gottlieb L. The social determinants of health: it's time to consider the causes of the causes. Public Health Rep 2014;129(Suppl 2):19-31.

32. Brennenstuhl S, Quesnel-Vallée A, McDonough P. Welfare regimes, population health and health inequalities: a research synthesis. $J$ Epidemiol Community Health 2012;66:397-409.

33. Burstrom B, Whitehead M, Clayton S, et al. Health inequalities between lone and couple mothers and policy under different welfare regimes - the example of Italy, Sweden and Britain. Soc Sci Med 2010;70:912-20.

34. Richardson D. Good pratices in anti-poverty family-foscused policies and programmes in developped countries. OCDE. 2013. http://www. un.org/esa/socdev/family/docs/egm12/PAPER-RICHARDSON.pdf (accessed 18 Jan 2018)

35. Förster $M$, Richardson $D$. Réduction de la pauvreté des enfants : comparaisons internationales. Politiques sociales et familiales 2011;104:63-75.

36. Gauthier $\mathrm{AH}$. Family Policies in Industrialized Countries: Is There Convergence? Population 2002;57:447

37. Cattoir P, Jacobs D. La politique familiale en Belgique : quels instruments pour quels objectifs? Rev Belge Sécurité Soc 1998.

38. B.-Dandurand R, Kempeneers M. Pour une analyse comparative et contextuelle de la politique familiale au Québec. Rech Sociogr 2002;43:49.

39. Bradshaw J, Hoelscher P, Richardson D. Comparing Child WellBeing in OECD Countries: Concepts and Methods. Florence: UNICEF Innocenti Research Centre, 2007.

40. Van Lancker W, Ghysels J, Cantillon B. The impact of child benefits on single mother poverty: Exploring the role of targeting in 15 European countries: Child benefits, targeting and single mother poverty. Int J Soc Welf 2015;24:210-22.

41. Jeandidier B. L'analyse des dimensions redistributives des politiques familiales [Des méthodes et des résultats qui stimulent la curiosité]. Recherches et Prévisions 1997;48:5-26.
42. Math A, Meilland C. Comparaison du soutien financier apporté aux familles dans douze pays européens. Recherches et Prévisions 2007;90:55-68.

43. Bradshaw J, Finch N. A comparison of child benefit packages in 22 countries. Department for Work and Pensions Research Report, No. 17. Corporate Document Services 2002. http://eprints. whiterose.ac. uk/73510/1/Document.pdf

44. Bambra C. Going beyond The three worlds of welfare capitalism: regime theory and public health research. J Epidemiol Community Health 2007;61:1098-102.

45. Esping-Andersen G. The three worlds of welfare capitalism. Princeton, N.J: Princeton University Press, 1990:248.

46. Whitehead M, Burström B, Diderichsen F. Social policies and the pathways to inequalities in health: a comparative analysis of lone mothers in Britain and Sweden. Soc Sci Med 2000;50:255-70.

47. Fritzell S, Vannoni F, Whitehead M, et al. Does non-employment contribute to the health disadvantage among lone mothers in Britain, Italy and Sweden? Synergy effects and the meaning of family policy. Health Place 2012;18:199-208.

48. Bernier NF. Le désengagement de l'État providence. Montréal, Qué: Presses de l'Université de Montréal, 2003:276. Politique et économie.

49. Coburn D. Beyond the income inequality hypothesis: class, neoliberalism, and health inequalities. Soc Sci Med 2004;58:41-56.

50. Observatoire de la Santé et du Social de Bruxelles-Capitale. Baromètre social. Rapport bruxellois sur l'état de la pauvreté. Bruxelles: Commission communautaire commune. 2016. http://www. brudoc.be/opac_css/doc_num.php?explnum_id=1449 (accessed 12 Oct 2017).

51. Centre d'étude sur la pauvreté et l'exclusion. La pauvreté, les inégalités et l'exclusion sociale au Québec: Etat de situation. 2012. https://www.mess.gouv.qc.ca/publications/pdf/CEPE_Etat_situation 2012.pdf (accessed 21 Nov 2017).

52. Hercot D, Mazina D, Verduyckt P, et al. Naître Bruxellois(e): Indicateurs de santé périnatale des bruxelleois(es) 2000-2012. Bruxelles: Observatoire de la Santé et du Social de BruxellesCapitale, Commission communautaire commune, 2015.

53. St-Arnaud-Trempe E, Defay F, Springmann V, et al. État de situation sur la santé des Montréalais et ses déterminants - 2014. Montreal, QC: Direction de santé publique de l'Agence de la santé et des services sociaux de Montréal, 2014

54. Régie des rentes-Québec. Montant et paiement du Soutien aux enfants. http://www.rrq.gouv.qc.ca/fr/programmes/soutien_enfants/ paiement/Pages/montant.aspx (accessed Dec 2017).

55. Agence fédérale pour les allocations familiales (FAMIFED). Allocations familiales de base et suppléments. http://dg.famifed.be/ $\mathrm{fr} /$ (accessed Dec 2017)

56. Aide sociale-CPAS. Portail belgium.be. http://www.belgium.be/fr/ famille/aide_sociale/cpas/ (accessed Jan 2017).

57. Emploi Québec. Aide Sociale. http://www.emploiquebec.gouv.qc ca/citoyens/obtenir-une-aide-financiere/aide-sociale (accessed November 2017)

58. Le CPAS (Centre Public d'Action Sociale). qu'est-ce que c'est? http://www.ocmw-info-cpas.be/fiche_FV_fr/le_cpas\#m4 (accessed Jan 2017).

59. Math A. Les politiques d'aides aux familles dans seize pays européens [Une comparaison par la méthode des cas types] Recherches et Prévisions 2004;78:31-50.

60. Raynault M, Bernard P, Jenson J, et al. Pauvreté et monoparentalité: Ce que peuvent nous apprendre les comparaisons internationales et interprovinciales croisant situations sociales et politiques publiques. Research report. Projet 2007-AC-118826. Fonds de recherche du Québec - Société Culture (FRQSC). 2010. http://www.frqsc.gouv. qc.ca/documents/11326/449016/PT_RaynaultMF_rapport+2010 comparaisons+intern-pauvret\%C3\%A9-monoparentalit\%C3\%A9/ cc14b575-ce47-4ef5-89a9-a475d46f990e.

61. Nelson K. Social assistance and minimum income benefits in old and new EU democracies. Int J Soc Welf 2010;19:367-78.

62. Løyland B, Miaskowski C, Paul SM, et al. The relationship between chronic pain and health-related quality of life in long-term social assistance recipients in Norway. Qual Life Res 2010;19:1457-65.

63. Galobardes B, Shaw M, Lawlor DA, et al. Indicators of socioeconomic position (part 1). J Epidemiol Community Health 2006;60:7-12.

64. Statistics Canada. Dissemination area (DA). http://www12.statcan. gc.ca/census-recensement/2011/ref/dict/geo021-eng.cfm (accessed 2 February 2017).

65. Denny K, Davidson M-J. Les indicateurs socioéconomiques régionaux: des outils de recherche, de politiques et de planification axés sur les disparités d'état sanitaire. Rev Can Santé Publique 2012;103(supp 2):4-6. 
66. Blumenshine P, Egerter S, Barclay CJ, et al. Socioeconomic Disparities in Adverse Birth Outcomes. Am J Prev Med 2010;39:263-72.

67. Urquia ML, O'Campo PJ, Heaman MI. Revisiting the immigrant paradox in reproductive health: the roles of duration of residence and ethnicity. Soc Sci Med 2012;74:1610-21.

68. Gagnon AJ, Zimbeck M, Zeitlin J, et al. Migration to western industrialised countries and perinatal health: a systematic review. Soc Sci Med 2009;69:934-46.

69. Racape J, Schoenborn C, Sow M, et al. Are all immigrant mothers really at risk of low birth weight and perinatal mortality? The crucial role of socio-economic status. BMC Pregnancy Childbirth 2016;16:75.

70. Auger N, Luo ZC, Platt RW, et al. Do mother's education and foreign born status interact to influence birth outcomes? Clarifying the epidemiological paradox and the healthy migrant effect. J Epidemiol Community Health 2008;62:402-9.

71. Urquia ML, Frank JW, Moineddin R, et al. Immigrants' duration of residence and adverse birth outcomes: a population-based study. BJOG 2010;117:591-601.

72. Lynch J, Smith GD, Harper S, et al. Is income inequality a determinant of population health? Part 1. A systematic review. Milbank Q 2004;82:5-99.

73. Subramania SV, Kawachi I, Kennedy BP. Does the state you live in make a difference? Multilevel analysis of self-rated health in the US. Soc Sci Med 2001;53:9-19.

74. Kahn RS, Wise PH, Kennedy BP, et al. State income inequality, household income, and maternal mental and physical health: cross sectional national survey. BMJ 2000;321:1311-5.

75. Diderichsen F, Evans T, Whitehead M. et a/The social basis of disparities in health. In: Evans T, Whitehead M, Diderichsen F, Bhuiya
A, Wirth M, . eds. Challenging inequities in health from ethics to action. New York: Oxford University Press, 2001:13-23.

76. Cole BL, Fielding JE. Health impact assessment: a tool to help policy makers understand health beyond health care. Annu Rev Public Health 2007;28:393-412.

77. Poland B, Frohlich KL, Cargo M. et alContext as a fundamental dimension of health promotion program evaluation. In: Potvin $\mathrm{L}$, McQueen DV, Hall M, de Salazar L, Anderson LM, . eds. Health Promotion Evaluation Practices in the Americas. New York, NY: Springer, 2008:299-317.

78. Potvin L, McQueen DV. et a/Practical dilemmas for health promotion evaluation. In: Potvin L, McQueen DV, Hall M, de Salazar L, Anderson LM, . eds. Health Promotion Evaluation Practices in the Americas. New York, NY: Springer, 2008:25-45

79. Mowat D, Chambers C. Producing more relevant evidence: applying a social epidemiology research agenda to public health pratice. In: O'Campo P, Dunn JR, eds. Rethinking social epidemiology: Towards a science of change. New York, NY: Springer, 2012:93-108.

80. Subramanian SV, Chen JT, Rehkopf DH, et al. Comparing individualand area-based socioeconomic measures for the surveillance of health disparities: A multilevel analysis of Massachusetts births, 1989-1991. Am J Epidemiol 2006;164:823-34.

81. Geronimus AT. Invited commentary: Using area-based socioeconomic measures--think conceptually, act cautiously. Am J Epidemiol 2006;164:835-40.

82. Misra DP, Guyer B, Allston A. Integrated perinatal health framework. A multiple determinants model with a life span approach. Am J Prev Med 2003;25:65-75. 